\title{
Psychological Effects of Quarantine During Covid-19: Students Attitude Towards Their Academics
}

\author{
Prof. Dr. Abdul Waheed Mughal, Dean, Faculty of Arts, Social Sciences and Education, Sarhad University of \\ Sciences \& Information Technology, Peshawar (SUIT), Pakistan \\ Dr. Khisro Kaleem Raza, Associate Professor/Head, Department of Education, SUIT, Peshawar, Pakistan \\ *Dr. Obaid Ullah, Lecturer and Coordinator, Department of Education, National University of Modern \\ Languages, Islamabad, Pakistan, obaid@numl.edu.pk, ORCID: https://orcid.org/0000-0003-3945-2883 \\ *Corresponding Author
}

\begin{abstract}
The current research aims to explore the effects of COVID-19 on students' academic achievements during the quarantine period through online mode of education and the effects of stress and anxiety on students' learning during quarantine. The nature of the study was descriptive research using validated close ended 5 point Likert scale questionnaire as tool of data collection. The questionnaire contains two main themes followed by ten items in each theme. The data was collected from 150 undergraduate level students via Google form, which was analyzed through Ordinal Regression Analysis (ORA). The results of the study show that attitude of students towards online classes was negative, quarantine period was difficult for students and leads to psychological issues. The study recommends that mental exercise be given to students to abstain from psychological stress and motivate the students towards online mode of teaching and learning process.
\end{abstract}

Keywords: Anxiety, COVID -19, Quarantine, Psychological Effect, Academics

Received: 08.12.2020 Accepted: 20.01.2021 $\quad$ Published: 03.02.2021

\section{INTRODUCTION}

In December 2019, an outbreak from China was reported namely COVID-19 which spread across the globe in a very short period affecting every run of life. The entire world took precautionary measures advised from their concerned health departments time to time and case to case aiming to reduce the rate of transmission. During the COVID 19, it is imperative to develop understanding about the symptoms of ailments caused by stress from quarantine and with that of corona virus (Bai et al., 2004; Liu et al., 2012; Wu et al., 2009). Severe Acute Respiratory Syndrome (SARS) and equine influenza was recorded which camouflaged with other ailments thus giving psychological stress to students (Rith-Najarian, Boustani, Chorpita, 2019; Sprang \& Silman, 2013; Taylor et al., 2008). During the class, when student suffer with any type of nonpathogenic influenza, other students seems reluctant to interact with that particular student. In order to cope up with the current scenario, it seems imperative to conduct study on the psychological effects of quarantine on students learning during the pandemic.

During the COVID-19 epidemic related control measures, specifically social distancing and isolation, had pernicious effect on the mental, economic and emotional aspects of general population worldwide, which in a way also affected students repose towards their studies. In particular, anger, depression and potential fear are specific reactions that reflect well-known trigger factors for a variety of behavioral disorders, including anxiety, which are affected by post-traumatic stress disorder (Meo et al., 2020).

In the recent outbreak of COVID 19 pandemic, strict precautionary measures were taken by governments across the globe in order to control the spread of respiratory ailments, which also include the mechanism of quarantine. In quarantine period, the individual, who have doubt of possible contact of with any contagious person or things are kept in isolation and curtailed the degree of contact with that specific person(s) in order to reduce the spread of ailment. Quarantine mechanism was first introduced in Italy in 1127 during the outbreak of malaria and later on officially announced by United Kingdom. This mechanism was most commonly used in 2019 due to Coronavirus and found to be hard for those who were experiencing it (Duraku \& Hoxha, 2020). 
The psychological effect of quarantine has direct impact on education and students attitude towards their academics. So far the COVID 19 pandemic situations, there is not clear idea about the reopening of educational institutes and it seems that the future of education could be online and campus free. The students' attitude towards online education even at tertiary level is not positive because of the low computer skills, technological anxiety, and application of computer hardware and poor study skills of students (Ullah, O., Khan, W., Khan, A., 2017).

The first outbreak of COVID-19 was reported on 26 February 2020 in Pakistan and the spread was so tremendous that the condition of entire country got worse. The government implemented lockdown on 23 March 2020 aiming to control the situations. During this lockdown, all the educational institutes across the country were closed fostering the concept of quarantine. Meanwhile, the health authorities promote the concept of isolation and social distancing for 6 feet which develops loneliness, disconnection and fear for virus. These precautionary measures were effective to reduce the impact of corona virus but at the same time it seems hard for students to cope up with their academic activities. Individual who got affected from corona virus were quarantined and was so unpleasant and tough for people to manage to work and study from home (Imran, Ameer, Imran, \& H, 2020).

Being a stressful situation of quarantine, the performance of students directly gets affected during the COVID - 19 pandemic. The students couldn't concentrate on their academics because of psychologically stressful, feeling hopeless and loss of interest. During COVID-19 pandemic, the parent of students lost their jobs due to institutional downsizing, which create economic stress among their families. The students whose parents lost jobs were more disturbed emotionally and their interest got lost in academics. The students as well as teachers work on weekends and even holidays, because of technological constraints and developing their understanding towards the technologies. The academic institutions launched various training to teachers and students for developing capacity building towards the application of gadgets for online teaching and learning. In due course of time, the academic institutes shift from conventional mode of teaching and learning to online mode. Such rapid and sudden shift of conventional mode of teaching to online mode cause delayed in conducting timely classes, marking assessments, and even prolonged the time period of semester (Guo, Yu, Luo \& Jiang, 2020; Duraku \& Hoxha, 2020).

The COVID-19 pandemic disturb the learning process of numerous students in 129 countries and number of academic institutes directly switched to online mode of teaching and learning process (UNESCO, 2020). This paradigm shift cause disturbance among the students toward their academic career and induced psychological stress and anxiety. A study conducted on the performance of students in their academics in China reveals that the online mode of teaching learning affects the grades of students and cause high level of depression and anxiety among them (Bao, 2020; Cao et al., 2020; Wang, 2020). The results of the study revealed that tertiary level students had severe anxiety, moderate anxiety and mild anxiety of $0.9 \%, 2.7 \%$ and $21.3 \%$ respectively. In this study, 7143 students took part regarding their learning during pandemics.

In another study made by Wang et al, (2020) on 1210 students from 194 cities in China, it was evident that $53.8 \%$ of students were suffering from moderate psychological effects where the rate of female students was high.

Towards online learning, students are facing anxiety and do not have expertise in the technologies which makes the condition more pathetic. In most cases, those students who belong to remote area, have no facilities i.e. internet facility, personal computer, laptop and other learning associated gadgets and software. Thus these students eventually go for freezing their semesters which affects their academic careers. The achievements score of such students are low in their academic and hence the depression develops among them (Rehman et al, 2020).

The findings of current study could help the concerned stakeholders of academic institutes in framing strategies which helps the students in managing their psychology during quarantine and perform the given tasks with confidence.

\section{Research Objectives}

The objectives of the study were to:

i. $\quad$ Explore the effects of stress and anxiety on students learning during quarantine

ii. Explore the effects of COVID-19 on student's academic performance using online mode of education 


\section{Research Hypotheses}

The research hypotheses of the study were to:

i. $\mathrm{H}_{\mathrm{o}}$ : The academic achievement of students was not comprised during quarantine period.

$\mathrm{H}_{1}$ : The academic achievement of students was comprised during quarantine period.

ii. $\mathrm{H}_{\mathrm{o}}$ : Students were not feeling anxiety during online learning.

$\mathrm{H}_{1}$ : Students were feeling anxiety during online learning.

\section{METHODOLOGY}

\section{Nature of the Study}

This study was descriptive in nature and was selected because of getting in-depth information from the respondents about the psychological effects of quarantine during COVID-19 and response of students towards their academics.

\section{Population of the Study}

The population constitutes all the undergraduate level students (221) of Department of Education, National University of Modern Language, Islamabad. Samples of 150 students were selected through random sampling using sample size determination techniques (Morgan \& Krijice, 1970).

\section{Development of Research Instrument}

A closed ended questionnaire with five points Likert scale was developed. The options for items were Strongly Agree (SA), Agree (A), Neutral (N), Disagree (DA) and strongly disagree (SDA). The questionnaire consists of two main themes and each theme contains 10 items. All the items have the reflection of research objectives and research hypotheses.

\section{Validity of the instrument}

The questionnaire was validated through focus group design where the questionnaire was checked for content, construct and face validity by experts in the relevant field. The Q-technique was made for validating the questionnaire at initial stages, while at the final stage, Average Extracted Variances (AEV) was made having values of 0.78 with composite reliability of 0.69 , which means that the validity of construct was high (Fornell \& Larker, 1981).

\section{Pilot Study}

After validating the questionnaire, a pilot study was made for which the sample was selected through rule of thumb. The sample selected for pilot study was 50 students from undergraduate level and not included in the actual study. The data was collected from the respondents and the reliability coefficient of Cronbach alpha was $0.6(0.4-0.9)$, which means that the questionnaire was suitable for collection of data.

\section{Data Collection}

Due to pandemic situations, all the educational institutes were closed by Government in order to avoid the spread of COVID-19. So the questionnaire was generated on Google forms and then sends the link (https://docs.google.com/forms/d/102tr1eDHFvwgoCsNVkW05IRrpiPm5nutr7LkhuebuRA/edit) to all the 150 respondents for data collection through emails. The mode of data collection was online and computer assisted.

\section{Data Analysis}

The collected data was preceded on Statistical Package for Social Sciences (SPSS v.20) and was analyzed by applying Ordinal Regression Analysis (ORA). The ORA was applied on the data because the nature of variable was dependent, number of sample size was 150 and scale of measurement was Ordinal (Johnson \& Christensen, 2017). 


\section{DISCUSSIONS AND RESULT}

This section shows the results of data analyzed using Ordinal Regression Analysis. There were two main themes i.e. psychological effects of quarantine during COVID - 19 and response of students towards their learning, which were followed by 10 items in each. The ORA provides marginal percentage and pseudo $\mathrm{R}$ square with model fit values which helps in interpreting the hypotheses.

The response rate from respondents was $100 \%$ and the distribution was $96(64 \%)$ respondents were female and 54 (36) respondents were male which shows the dominancy of female students at undergraduate level.

Table 1. Gender based distribution of students

\begin{tabular}{|l|l|l|}
\hline Gender & Frequency & Percentage \\
\hline Male & 54 & 36 \\
\hline Female & 96 & 64 \\
\hline Total & 150 & 100 \\
\hline
\end{tabular}

Table 2. Psychological effects of quarantine during COVID-19

\begin{tabular}{|c|c|c|c|c|}
\hline S. No. & Statements & Responses & $\mathbf{N}$ & $\begin{array}{l}\text { Marginal } \\
\%\end{array}$ \\
\hline \multirow[t]{5}{*}{1.} & \multirow{5}{*}{$\begin{array}{l}\text { The situation of COVID-19 gives anxiety to the students on } \\
\text { daily basis. }\end{array}$} & SDA & 3 & $2.0 \%$ \\
\hline & & DA & 10 & $6.7 \%$ \\
\hline & & $\mathrm{N}$ & 17 & $11.3 \%$ \\
\hline & & $\mathrm{A}$ & 79 & $52.7 \%$ \\
\hline & & SA & 40 & $26.7 \%$ \\
\hline \multirow[t]{5}{*}{2.} & \multirow{5}{*}{$\begin{array}{l}\text { Student quarantined due to COVID } 19 \text { directly affects the } \\
\text { emotions of the students. }\end{array}$} & SDA & 3 & $2.0 \%$ \\
\hline & & DA & 10 & $6.7 \%$ \\
\hline & & $\mathrm{N}$ & 13 & $8.7 \%$ \\
\hline & & A & 82 & $54.7 \%$ \\
\hline & & SA & 42 & $28.0 \%$ \\
\hline \multirow[t]{5}{*}{3.} & \multirow{5}{*}{$\begin{array}{l}\text { Student having high knowledge about COVID-19 affects the } \\
\text { mental health in a negative way. }\end{array}$} & SDA & 4 & $2.7 \%$ \\
\hline & & DA & 26 & $17.3 \%$ \\
\hline & & $\mathrm{N}$ & 28 & $18.7 \%$ \\
\hline & & $\mathrm{A}$ & 61 & $40.7 \%$ \\
\hline & & SA & 31 & $20.7 \%$ \\
\hline \multirow[t]{5}{*}{4.} & \multirow{5}{*}{$\begin{array}{l}\text { Quarantine is often an unpleasant experience for those who } \\
\text { undergo it. }\end{array}$} & SDA & 1 & $0.7 \%$ \\
\hline & & $\mathrm{DA}$ & 12 & $8.0 \%$ \\
\hline & & $\mathrm{N}$ & 24 & $16.0 \%$ \\
\hline & & $\mathrm{A}$ & 81 & $54.0 \%$ \\
\hline & & SA & 32 & $21.3 \%$ \\
\hline \multirow[t]{5}{*}{5.} & \multirow{5}{*}{$\begin{array}{l}\text { Prolong period of quarantine enhance the psychological } \\
\text { distress among students. }\end{array}$} & SDA & 4 & $2.7 \%$ \\
\hline & & DA & 6 & $4.0 \%$ \\
\hline & & $\mathrm{N}$ & 29 & $19.3 \%$ \\
\hline & & A & 72 & $48.0 \%$ \\
\hline & & SA & 39 & $26.0 \%$ \\
\hline \multirow[t]{5}{*}{6.} & \multirow{5}{*}{$\begin{array}{l}\text { Prolong period of quarantine develops practice of anger and } \\
\text { mood disorder. }\end{array}$} & SDA & 4 & $2.7 \%$ \\
\hline & & DA & 6 & $4.0 \%$ \\
\hline & & $\mathrm{N}$ & 29 & $19.3 \%$ \\
\hline & & $\mathrm{A}$ & 72 & $48.0 \%$ \\
\hline & & SA & 39 & $26.0 \%$ \\
\hline \multirow[t]{4}{*}{7.} & \multirow{4}{*}{$\begin{array}{l}\text { Quarantine has caused people to feel emotionally detached } \\
\text { from family, fellows and friends. }\end{array}$} & SDA & 9 & $6.0 \%$ \\
\hline & & DA & 23 & $15.3 \%$ \\
\hline & & $\mathrm{N}$ & 26 & $17.3 \%$ \\
\hline & & $\mathrm{A}$ & 65 & $43.3 \%$ \\
\hline
\end{tabular}




\begin{tabular}{|c|c|c|c|c|}
\hline & & SA & 27 & $18.0 \%$ \\
\hline \multirow[t]{5}{*}{8.} & \multirow{5}{*}{$\begin{array}{l}\text { Student quarantine for prolonged period of time develops } \\
\text { moves towards the state of depression. }\end{array}$} & SDA & 6 & $4.0 \%$ \\
\hline & & DA & 9 & 6.05 \\
\hline & & $\mathrm{N}$ & 29 & $19.3 \%$ \\
\hline & & $\mathrm{A}$ & 88 & $58.7 \%$ \\
\hline & & SA & 18 & $12.0 \%$ \\
\hline \multirow[t]{5}{*}{9.} & \multirow{5}{*}{$\begin{array}{l}\text { Negative psychological effects develop among students which } \\
\text { include post-traumatic stress symptoms, confused with lack } \\
\text { of control on behavior due to quarantine. }\end{array}$} & SDA & 2 & $1.3 \%$ \\
\hline & & $\mathrm{DA}$ & 10 & $6.7 \%$ \\
\hline & & $\mathrm{N}$ & 21 & $14.0 \%$ \\
\hline & & $\mathrm{A}$ & 94 & $62.7 \%$ \\
\hline & & SA & 23 & $15.3 \%$ \\
\hline \multirow[t]{5}{*}{10} & \multirow{5}{*}{$\begin{array}{l}\text { Quarantine has decreased overall work performance and } \\
\text { study period. }\end{array}$} & SDA & 3 & $2.0 \%$ \\
\hline & & DA & 21 & $14.0 \%$ \\
\hline & & $\mathrm{N}$ & 22 & $14.7 \%$ \\
\hline & & $\mathrm{A}$ & 60 & $40.0 \%$ \\
\hline & & SA & 44 & $29.3 \%$ \\
\hline
\end{tabular}

Table 2 showed that $26.7 \%$ respondents strongly agreed, $52.7 \%$ respondents agreed, $6.7 \%$ disagree and $2 \%$ were strongly disagreeing respectively with the statement "The situation of COVID-19 gives anxiety to the students on daily basis". Among the total sample respondents, $11.3 \%$ of the respondents remained neutral.

The table 2 shows that $28 \%, 54.7 \%, 6.7 \%$ and $2 \%$ of the respondents strongly agreed, agreed, disagree and strongly disagree respectively to the statement "Student quarantined due to COVID 19 directly affects the emotions of the students". Among the total sample respondents, $8.7 \%$ of the respondents remained neutral.

Table 2 reveals that $20.7 \%, 40.7 \%, 17.3 \%$ and $2.7 \%$ of the respondents strongly agreed, agreed, disagree and strongly disagreed respectively to the statement "Student having high knowledge about COVID19 affects the mental health in a negative way". Among the total sample respondents, $18.7 \%$ of the respondents remained neutral.

The table 2 reveals that $21.3 \%, 54 \%, 8 \%$ and $0.7 \%$ of the respondents strongly agreed, agreed, disagrees and strongly disagreed respectively to the statement "Quarantine is often an unpleasant experience for those who undergo it". Among the total sample respondents, $16.0 \%$ of the respondents remained neutral.

The table 2 shows that $26 \%, 48 \%, 4 \%, 2.7 \%$ respondents strongly agreed, agreed, disagreed and strongly disagree respectively to the statement "Prolong period of quarantine enhance the psychological distress among students". Among the total sample respondents, $19.3 \%$ of the respondents remained neutral.

The table 2 shows that $26 \%, 48 \%, 4 \%$ and $2.7 \%$ of the respondents strongly agreed, agreed, disagreed and strongly disagree respectively to the statement "Prolong period of quarantine develops practice of anger and mood disorder". Among the total sample respondents, $19.3 \%$ of the respondents remained neutral.

The table 2 reveals that $18 \%, 43.3 \%, 15.3 \%$ and $6 \%$ of the respondents strongly agreed, agreed, disagree and strongly disagree respectively to the statement "Quarantine has caused people to feel emotionally detached from family, fellows and friends". Among the total sample respondents, $17.3 \%$ of the respondents remained neutral.

Table 2 further reveals that $12 \%, 58.7 \%, 6 \%$ and $4 \%$ of the respondents strongly agreed, agreed, disagreed and strongly disagree respectively to the statement "Student quarantine for prolonged period of time develops moves towards the state of depression". Among the total sample respondents, $19.3 \%$ of the respondents remained neutral.

The table 2 states that $15.3 \%, 62.7 \%, 6.7 \%$ and $1.3 \%$ of the respondents strongly agreed, agreed, disagree and strongly disagree respectively to the statement "Negative psychological effects develop among students which include post-traumatic stress symptoms, confused with lack of control on behavior due to quarantine". Among the total sample respondents, $14 \%$ of the respondents remained neutral.

Furthermore the table 2 shows that $29.3 \%, 40 \%, 14 \%$ and $2 \%$ of the respondents strongly agreed, agreed, disagreed and strongly disagreed respectively to the statement "Quarantine has decreased overall 
work performance and study period". Among the total sample respondents, $14.7 \%$ of the respondents remained neutral.

\section{Model Fitting Information}

The below model fitting information indicated that at $p(0.05)$ and degree of freedom 23 , the fit of the model was rejected as the value of chi square was greater than the tabulated values.

Table 3. Model Fitting Information

\begin{tabular}{|l|l|l|l|}
\hline Model & $\mathbf{- 2} \log$ Likelihood & $\boldsymbol{x}^{\mathbf{2}}$ test & Degree of freedom \\
\hline Intercept only & 115.787 & & \multirow{2}{*}{23} \\
\cline { 1 - 3 } Final & 142.581 & 45.238 & \\
\hline
\end{tabular}

\section{Goodness-of-Fit}

The model of Goodness of Fit model information indicated that at 0.05 level of significance and 234 degree of freedom, the model was rejected as the calculate of chi square was greater than the tabulate values which means that the null hypothesis $\left(\mathrm{H}_{0}\right)$ "the academic achievement of students was not comprised during quarantine period" was rejected and accept the alternative hypothesis "the academic achievement of students was comprised during quarantine period".

Table 4. Goodness of fit

\begin{tabular}{|l|l|l|l|}
\hline & Chi - square & Df & Sig. \\
\hline Pearson & 271.182 & 234 & .211 \\
\hline Deviance & 162.421 & 234 & 1.000 \\
\hline
\end{tabular}

\section{Pseudo R-Square}

A post hoc treatment was made in order to check the rejection of null hypothesis (Ho), pseudo R square was made. The result of post hoc treatment was moderately increased indicating a moderate fit. Thus it can be concluded that we could accept the rejection of our null hypothesis.

Table 5. Pseudo R-Square

\begin{tabular}{|l|l|}
\hline Cox and Snell & .535 \\
\hline Nagelkerke & .670 \\
\hline McFadden & .310 \\
\hline
\end{tabular}

Table 6. Students' response towards their academics

\begin{tabular}{|c|c|c|c|c|}
\hline S. No. & Statements & Responses & $\mathrm{N}$ & Marginal \% \\
\hline \multirow[t]{5}{*}{1.} & \multirow{5}{*}{ Online classes are not accommodative for students. } & SDA & 4 & $2.7 \%$ \\
\hline & & DA & 16 & $10.7 \%$ \\
\hline & & $\mathrm{N}$ & 23 & $15.3 \%$ \\
\hline & & A & 57 & $38.0 \%$ \\
\hline & & SA & 50 & $33.3 \%$ \\
\hline \multirow[t]{5}{*}{2.} & \multirow{5}{*}{$\begin{array}{l}\text { Online learning affects examinations and assessment } \\
\text { mechanisms. }\end{array}$} & SDA & 4 & $2.7 \%$ \\
\hline & & DA & 7 & $4.7 \%$ \\
\hline & & $\mathrm{N}$ & 20 & $13.3 \%$ \\
\hline & & A & 81 & $54.0 \%$ \\
\hline & & SA & 38 & $25.3 \%$ \\
\hline \multirow[t]{5}{*}{3.} & \multirow{5}{*}{$\begin{array}{l}\text { The academic careers of students may be severely } \\
\text { affected by the COVID-19 pandemic. }\end{array}$} & SDA & - & - \\
\hline & & DA & 12 & $8.0 \%$ \\
\hline & & $\mathrm{N}$ & 22 & $14.7 \%$ \\
\hline & & $\mathrm{A}$ & 68 & $45.3 \%$ \\
\hline & & SA & 48 & $32.0 \%$ \\
\hline \multirow[t]{2}{*}{4.} & \multirow{2}{*}{$\begin{array}{l}\text { Internet issues for students directly affect the students' } \\
\text { academic achievements. }\end{array}$} & SDA & 2 & $1.3 \%$ \\
\hline & & DA & 9 & $6.0 \%$ \\
\hline
\end{tabular}




\begin{tabular}{|c|c|c|c|c|}
\hline & & $\mathrm{N}$ & 19 & $12.7 \%$ \\
\hline & & $\mathrm{A}$ & 68 & $45.3 \%$ \\
\hline & & SA & 52 & $34.7 \%$ \\
\hline \multirow[t]{5}{*}{5.} & \multirow{5}{*}{$\begin{array}{l}\text { Students do not show interest in their education during } \\
\text { online education. }\end{array}$} & SDA & 3 & $2.0 \%$ \\
\hline & & DA & 13 & $8.7 \%$ \\
\hline & & $\mathrm{N}$ & 25 & $16.7 \%$ \\
\hline & & A & 59 & $39.3 \%$ \\
\hline & & SA & 50 & $33.3 \%$ \\
\hline \multirow[t]{5}{*}{6.} & \multirow{5}{*}{$\begin{array}{l}\text { Students are continuously protesting against online } \\
\text { classes instead of taking interest and working hard for } \\
\text { learning. }\end{array}$} & SDA & 4 & $2.7 \%$ \\
\hline & & DA & 18 & $12.0 \%$ \\
\hline & & $\mathrm{N}$ & 16 & $10.7 \%$ \\
\hline & & $\mathrm{A}$ & 79 & $52.7 \%$ \\
\hline & & SA & 33 & $22.0 \%$ \\
\hline \multirow[t]{5}{*}{7.} & \multirow{5}{*}{$\begin{array}{l}\text { Ipsative assessment is negatively inclined in comparison } \\
\text { with the previous results. }\end{array}$} & SDA & 3 & $2.0 \%$ \\
\hline & & DA & 15 & $10.0 \%$ \\
\hline & & $\mathrm{N}$ & 19 & $12.7 \%$ \\
\hline & & $\mathrm{A}$ & 75 & $50.0 \%$ \\
\hline & & SA & 38 & $25.3 \%$ \\
\hline \multirow[t]{5}{*}{8.} & \multirow{5}{*}{$\begin{array}{l}\text { Students are familiar to attend classes online after this } \\
\text { pandemic. }\end{array}$} & SDA & 8 & $5.3 \%$ \\
\hline & & DA & 18 & $12.0 \%$ \\
\hline & & $\mathrm{N}$ & 24 & $16.0 \%$ \\
\hline & & $\mathrm{A}$ & 64 & $42.7 \%$ \\
\hline & & SA & 36 & $24.0 \%$ \\
\hline \multirow[t]{5}{*}{9.} & \multirow{5}{*}{$\begin{array}{l}\text { Students prefer to freeze their semester instead of } \\
\text { studying online. }\end{array}$} & SDA & 6 & $4.0 \%$ \\
\hline & & DA & 28 & $18.7 \%$ \\
\hline & & $\mathrm{N}$ & 21 & $14.0 \%$ \\
\hline & & $\mathrm{A}$ & 64 & $42.7 \%$ \\
\hline & & SA & 31 & $20.7 \%$ \\
\hline \multirow[t]{5}{*}{10.} & \multirow{5}{*}{$\begin{array}{l}\text { Student assignments and quizzes are mostly on pending } \\
\text { or incomplete whenever student does it online which } \\
\text { directly affects the students' academic result. }\end{array}$} & SDA & 2 & $1.3 \%$ \\
\hline & & DA & 7 & $4.7 \%$ \\
\hline & & $\mathrm{N}$ & 26 & $17.3 \%$ \\
\hline & & $\mathrm{A}$ & 81 & $54.0 \%$ \\
\hline & & SA & 34 & $22.7 \%$ \\
\hline
\end{tabular}

Table 6 shows that $33.3 \%, 38 \%, 10.7 \%$ and $2.7 \%$ of the respondents strongly agreed, agreed, disagreed and strongly disagree respectively to the statement "Online classes are not accommodative for students". Among the total sample respondents, $15.3 \%$ of the respondents remained neutral.

Table 6 shows that $25.3 \%, 54 \%, 4.7 \%$ and $2.7 \%$ of the respondents strongly agreed, agreed, disagreed and strongly disagree respectively to the statement "Online learning affects examinations and assessment mechanisms". Among the total sample respondents, $13.3 \%$ of the respondents remained neutral.

Table 6 reveals that $32 \%, 45.3 \%$, and $8 \%$ of the respondents strongly agreed, agreed, $8.0 \%$ disagreed respectively to the statement "The academic careers of students may be severely affected by the COVID-19 pandemic". Among the total sample respondents, $14.7 \%$ of the respondents remained neutral.

Table 6 shows that $34.7 \%, 45.3 \%, 6 \%$ and $1.3 \%$ of the respondents strongly agreed, agreed, disagreed and strongly disagree respectively to the statement "Internet issues for students directly affect the students' academic achievements". Among the total sample respondents, $12.7 \%$ of the respondents remained neutral.

Similarly table 6 reveals that $33.3 \%, 39.3 \% 8.7 \%$ and $2 \%$ of the respondents strongly agreed, agreed, disagreed and strongly disagree respectively to the statement "Students do not show interest in their education during online education". Among the total sample respondents, $16.7 \%$ of the respondents remained neutral.

Table 6 shows that $22 \%, 52.7 \%, 12 \%$ and $2.7 \%$ of the respondents strongly agreed, agreed, disagreed and strongly disagree respectively to the statement "Students are continuously protesting against online 
classes instead of taking interest and working hard for learning". Among the total sample respondents, $10.7 \%$ of the respondents remained neutral.

Table 6 further shows that $25.3 \%, 50 \%, 10 \%$ and $2 \%$ of the respondents strongly agreed, agreed, disagreed and strongly disagree respectively to the statement "Ipsative assessment is negatively inclined in comparison with the previous results". Among the total sample respondents, $12.7 \%$ of the respondents remained neutral.

Furthermore the table 6 reveals that $24 \%, 42.7 \%, 12 \%$ and $5.3 \%$ of the respondents strongly agreed, agreed, disagreed and strongly disagree respectively to the statement "Students are familiar to attend classes online after this pandemic". Among the total sample respondents, $16 \%$ of the respondents remained neutral.

The table 6 shows that $20.7 \%, 42.7 \%, 18.7 \%$ and $4 \%$ of the respondents strongly agreed, agreed, disagreed and strongly disagree respectively to the statement "Students prefer to freeze their semester instead of studying online". Among the total sample respondents, $14 \%$ of the respondents remained neutral.

Similarly the table 6 shows that $22.7 \%, 54 \%, 4.7 \%$ and $1.3 \%$ of the respondents strongly agreed, agreed, disagreed and strongly strongly disagree respectively to the statement "Student assignments and quizzes are mostly on pending or incomplete whenever student does it online which directly affects the students' academic result". Among the total sample respondents, $17.3 \%$ of the respondents remained neutral.

\section{Model Fitting Information}

The below model fitting information indicated that at $p(0.05)$ and degree of freedom 36 , the fit of the model was rejected as the value of chi square was greater than the tabulated values.

Table 7. Model Fitting Information

\begin{tabular}{|l|l|l|l|}
\hline Model & $\mathbf{- 2} \log$ Likelihood & $\boldsymbol{x}^{\mathbf{2}}$ test & Degree of freedom \\
\hline Intercept only & 232.651 & & \multirow{2}{*}{36} \\
\hline Final & 128.572 & 81.21 & \\
\hline
\end{tabular}

\section{Goodness-of-Fit}

The model of Goodness of Fit model information indicated that at 0.05 level of significance and 251 degree of freedom, the model was rejected as the calculate of chi square was greater than the tabulate values which means that the null hypothesis $\left(\mathrm{H}_{0}\right)$ "students were not feeling anxiety during online learning" was rejected and accept the alternative hypothesis "students were feeling anxiety during online learning".

Table 8. Goodness of fit

\begin{tabular}{|l|l|l|l|}
\hline & Chi - square & Df & Sig. \\
\hline Pearson & 251.741 & 251 & .315 \\
\hline Deviance & 113.362 & 251 & 1.000 \\
\hline
\end{tabular}

\section{Pseudo R-Square}

A post hoc treatment was made in order to check the rejection of null hypothesis (Ho), pseudo R square was made. The result of post hoc treatment was moderately increased indicating a moderate fit. Thus it can be concluded that we could accept the rejection of our null hypothesis.

Table 9. Pseudo R-Square

\begin{tabular}{|l|l|}
\hline Cox and Snell & .651 \\
\hline Nagelkerke & .719 \\
\hline McFadden & .428 \\
\hline
\end{tabular}

\section{CONCLUSION}

This study explores the effects of psychological stress on the students' academics due to the quarantine in COVID-19 pandemic. The study concluded that the null hypothesis "the academic achievement of students was not comprised during quarantine period" was rejected. Mostly the academic achievement of students was curtailed due to uncertain conditions, high stress level, financial problems, problems in obtaining 
electronic gadgets, lack of technical knowledge, students suffering from COVID-19, and dwelling in rural areas and internet connectivity problems. Students were also facing problems in online learning reason being the institutional downsizing due to COVID-19, thus resulting in loss of their parents' jobs, which eventually caused economic stress.

It was also observed that the null hypothesis "students were not feeling anxiety during online learning" was rejected. The performance of students towards online learning was not positive because of the reason that they have no or least understanding in using the online application and gadgets. Several academic institutes switch to online mode of teaching and learning where the online application and software (Learning Management System; onward to be stated as LMS) fails to work because of huge load on servers. When maximum numbers of students' login to the LMS portal, the LMS got troubleshooting and the link got down. Such issues waste the time of students as well as the teachers and frustrate them causes delay in learning. The condition got more severe when a student was suffering from COVID-19 and was quarantine from the friends and family. Such students were in isolation and not suitable to come in contact with anyone which affects their learning. Because of least concentration and medical issues, the student fails to cope up with the complex and important academic concepts, thus directly affecting the academics of students.

\section{RECOMMENDATIONS}

The study recommends the following points:

1. Minimize watching, reading or listening to news about COVID-19 that causes stressful conditions.

2. Interact with family and friends through online mode using social media and phones during quarantine, so that the sense of loneliness may not depress the student.

3. Students facing internet connectivity may be accommodated and the academic institutes may provide hostels and provide recorded lectures.

\section{REFERENCES}

Bai, Y.; Lin, C.C.; Lin, C.Y.; Chen, J.Y.; Chue, C.M.; Chou, P. (2004). Survey of stress reactions among health care workers involved with the SARS outbreak. Psychiatr. Serv., 55, 1055-1057.

Bao, Y.; Sun, Y.; Meng, S.; Shi, J.; Lu, L. (2020). 2019-nCoV epidemic: Address mental health care to empower society. Lancet, 395, e37-e38.

Cao,W.; Fang, Z.; Hou, G.; Han, M.; Xu, X.; Dong, J.; Zheng, J. (2020) The psychological impact of the COVID-19 epidemic on college students in China. J. Psychiatry Res., 287, 112934.

Duraku, Z., \& Hoxha, L. (2020, May). The effect of COVID-19 on higher education : A study of interaction among students ' mental health, attitudes toward online learning, study skills, and changes in students ' life The effect of COVID-19 on higher education : A study of interaction among. the Lancet, Vol 395(ISSUE 10227), 9.

Fornell and Larker (1981) Evaluating Structural Equation Models with Unobservable Variables and Measurement Error. Journal of Marketing.

Guo, a. L., Yu, B. M., Luo, M., \& Jiang, C. W. (2020, June 7). The psychological and mental effect of coronavirus disease 2019 (COVID-19) on medical staff and general public - A systematic review and meta-analysis. journals.elsevier.com/psychiatry-research, Psychiatry Research 291, 10.

Imran, N., Ameer, I., Imran, M., \& H, Z. (2020 , July-August). Psychological burden of quarantine in children and adolescents. Pkaistan Journal Of Medical Science, Vol. $36,11$.

Johnson, B., and Christensen, L. (2017), Educational Research: Qualitative, Quantitative and Mixed method approaches, Sixth edition. Thousand Oaks, California: SAGE Publications, USA

Liu, X.; Kakade, M., Fuller, C.J. .(2012). Depression after exposure to stressful events: Lessons learned from the severe acute respiratory syndrome epidemic. Compr. Psychiatry, 53, 15-23.

Meo, S., Abukhalaf, A., Giallonardo Vincenzo, Sampogna, G., Vecchio, V., Luciano, M., \& Albert, U. (2020, June 5). The Effect of Quarantine and Physical Distancing Following COVID-19 on Mental Health: Study Protocol of a Multicentric Italian Population Trial. Frontier in phychiatry, 36, 43-48.

Rehman, U., Kharshiing, K. D., Shahnawaz, G., Khursheed, M., \& Gupta, K. (2020, June 23). Depression, Anxiety and Stress Among Indians in Times of Covid-19 Lockdown. Community Mental Health Journal, 7. Retrieved from https://doi.org/10.1007/s10597-020-00664-x 
Rith-Najarian, L.R.; Boustani, M.M.; Chorpita, B.F. (2019) A systematic review of prevention programs targeting depression, anxiety, and stress in university students. J. Affect. Disord., 257, 568-584.

Sprang, G.; Silman, M. (2013) Posttraumatic stress disorder in parents and youth after health-related disasters. Disaster Med. Public Health Prep., 7, 105-110.

Taylor, M.R.; Agho, K.E.; Stevens, G.J.; Raphael, B. (2008) Factors influencing psychological distress during a disease epidemic: Data from Australia's first outbreak of equine influenza. BMC Public Health, 8, 347.

Ullah, O., Khan, W., \& Khan, A. (2017, Feburary). Students' Attitude towards Online Learning at Tertiary Level. PUTAJ, Vol 25, 63-82.

United Nations Educational, Scientific and Cultural Organization (UNESCO). Available online: https://en.unesco.org/covid19/educationresponse (accessed on 20 Jan 2021).

Wang, G.; Zhang, Y.; Zhao, J.; Zhang, J.; Jiang, F. (2020) Mitigate the effects of home confinement on children during the COVID-19 outbreak. Lancet, 395, 945-947

World Health Organization. Coronavirus Disease (COVID-19) Pandemic. Available online: https://www.who.int/emergencies/diseases/novel-coronavirus-2019 (accessed on 18 Jan 2021).

Wu, P.; Fang, Y.; Guan, Z.; Fan, B.; Kong, J.; Yao, Z.; Liu, X.; Fuller, C.J.; Susser, E.; Lu, J.; et al. (2009) The psychological impact of the SARS epidemic on hospital employees in China: Exposure, risk perception, and altruistic acceptance of risk. Can. J. Psychiatry, 54, 302-311. 